\title{
磁化特性の簡易数式表現に基づく SRM の位置センサレス制御
}

$\begin{array}{lllllll}\text { 正員 小 坂 } & \text { 卓 } & \text { (名古屋工大) 非会員 Subrata Saha } & \text { (名古屋工大) } \\ \text { 正員 松 井 信 行 (名古屋工大) 正員 武 田 洋 次 (大阪府立大) }\end{array}$

Sensorless Control of SRM based on a Simple Expression of Magnetization Characteristics

Takashi Kosaka, Member, Nobuyuki Matsui, Member, Subrata Saha, Non-member (Nagoya Institute of Technology), Yoji Takeda, Member (Osaka Prefecture University)

Switched Reluctance Motors (SRM) have more simple and rugged construction compared to those of the conventional ac motors. Hence, SRM are suitable for low-cost variable-speed drives in many industrial applications. However, the need of a traditional position sensor for its control is one of the demerits of SRM from standpoints of cost, size and reliability. For practical use, the sensorless drive of SRM are expected.

This paper presents the position sensorless control of SRM based on a simple expression of non-linear magnetization characteristics. Successful experiments using $1.5 \mathrm{~kW}, 5,400 \mathrm{rpm}$ SRM with $6 / 4$ poles configuration have been performed for verifying the practicability of the proposed sensorless control scheme.

キーワード:スイッチトリラタタンスモータ, 位䈯センサレス制御, 磁化特性, 簡易数式表現

\section{1.まえがき}

スイッチトリラタタンスモータ (Switched Reluctance Motor 以下 SRM 上略記) は、誘導機やブラシレス DC モータなど従来の交流機に比心゙、構造的に簡箪かつ堅牢と いう特徴有し、安価な可変速駆動源乙して注目を集めて いる(1)(2)。SRMではそのトルク発生原理から、回転子位 置に応じた電流/電圧制御が要求され、一般的に注光学式る るいは磁気式の回転子位置センサがモー夕軸に取り付けら れている。しかし、位置セン并はシステムの大型化や信頼 性の低下を招き、設置環境加限定されるなどの問題点を有 し、コスト的にはSRM の安価さに対するトレードオフと なる。また、徒来の交流機では位置・速度センサレス化が 既に実用段階に入っており、SRMの位置センサレス化も同 様に、実用上、克服す心゙き課題となっている。

上述の課題に対し、これまで種々の回転子位置推定法が 提案されてきたが(3) (4)、SRMでは1. 出力/变換器容量、 出力密度の観点から磁気飽和領域交積極的に利用子ること、 2. 構造抢よび駆動方式から、一相の巻線電流一磁束鎖交数 と回転子位置が１対１の開倸存することに着目して、近 年では磁化特性に基つく位置推定法が主として提案される ようになった。この場合に核となる非線形磁化特性のモデ リング手法恃種々あるが、近年では、非線形な入出力関倸 の表現に適するファジイ推論やニューラルネットワークが

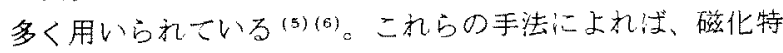

性モデルの構築に必要となるデータベース执よび位置推定 演算に要するメモリ空間が少なくてすむが、演算が複雑で オンラインでの演算時間が長大化するため、提案の多くて は高価な浮動小数点形DSP が用いられている。また、多 くは>ィージビリティスタディの域に留まって㧍り、実用 性の観点から運転特性が評価されている例は散見される程 度で孪る。

本諭文では、固定子/回転子突極が $6 / 4$ 構成で、定格出 力 $1.5 \mathrm{~kW}$ の三相 SRM を対象に、回転子位置の関数係数 在持つ電流多項式により、磁化特性の簡易数式表現 ${ }^{(7)}{ }^{\text {学構 }}$ 成し、これに基づく位置推定アルゴリズム在提案している。 さらに、固定小数点形DSP で静成した実験システムによ り、提案アルゴリズムの実用性在実験的に評価している。

\section{2. 供試 SRM $の$ 磁化特性}

本研究で用いたSRMの構造図を図 1亿、諸元变 1 示 寸。供試機在対象に、U 相固定子突極々回転子筷極の完全 非対向状態 (図 1(a)) 加它全対向状態 (㘣 1(b)) まて機械 角50每儿回転子位置索固定し、图20ようにU相巻線儿波 高值 $120 \mathrm{~V}$ のステッブ電生を与えた場合の電流時間応答波

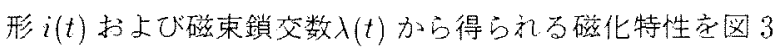
に示寺。ここで、回転子位置时U 相固定子突極已回転子 突極の完全対向時の突極中心紊原点に機械角で定義してお り、磁束鎖交数 $\lambda(t)$ は巻線印加電压在 $v_{p h}(t)$ 、測定され店 電流時間応答波形充 $i(t)$ 上して次式により求妨る。 


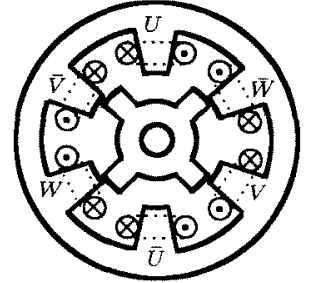

(a) 突極完全非詨向状態

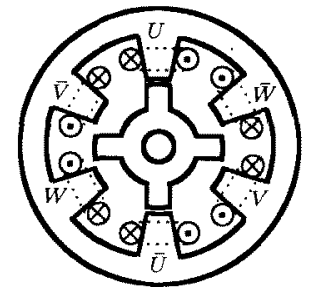

(b) 突極完全対向状態
図 1 供試 SRM の構造

Fig. 1. Construction of test motor.

表 1 供試 SRM の諸元

Table 1. Specifications of test motor.

\begin{tabular}{|c|c|c|c|}
\hline 回転子/固定子極数 & $6 / 4$ & ギヤップ長 & $0.25[\mathrm{~mm}$ \\
\hline 定格出力 & $1.5[\mathrm{~kW}]$ & 口-タ精厚 & $80[\mathrm{~mm}]$ \\
\hline 定格回転数 & $5400[\mathrm{rpm}]$ & 固定子突梪開解 & $30[\mathrm{deg}]$ \\
\hline 定格卜N夕 & $2.65[\mathrm{~N} \cdot \mathrm{m}]$ & 回転子突極開魚 & 45 [deg] \\
\hline ステータ外径 & $112[\mathrm{~mm}]$ & 巻数 / 相 & 80 \\
\hline 口ータ外径 & $60.5[\mathrm{~mm}]$ & 巻線抵抗/相 $R$ & $0.27[\Omega]$ \\
\hline
\end{tabular}

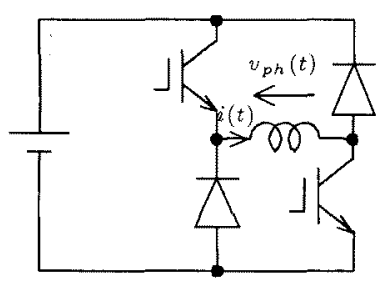

(a) 磁化特性測定回路

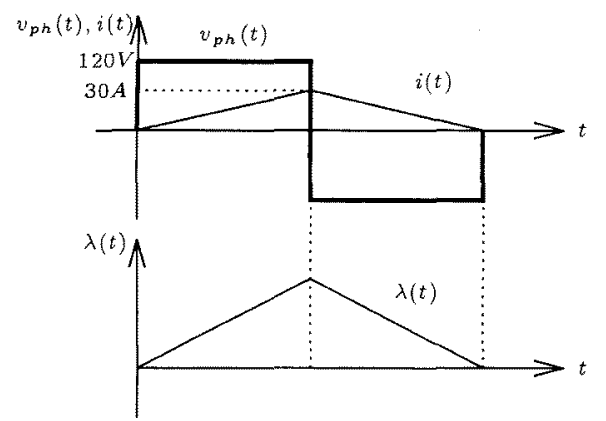

(b) 巻線電流および磁束鎖交数の時間応答波形

図 2 磁化特性の測定法

Fig. 2. Measurment method of magnetization characteristics.

$$
\lambda(t)=\int\left\{v_{p h}(t)-R \cdot i(t)\right\} d t
$$

な扔、図3で機械角 $5^{\circ}$ 毎の 10 点の位置に対し、対応子る 磁化曲線が 9 本しか見られないのは、供試機の場合では突 極対向近傍の $85^{\circ}$ と対向時 $90^{\circ}$ の磁化曲線がほぼ同じ曲線 で重なっているためである。

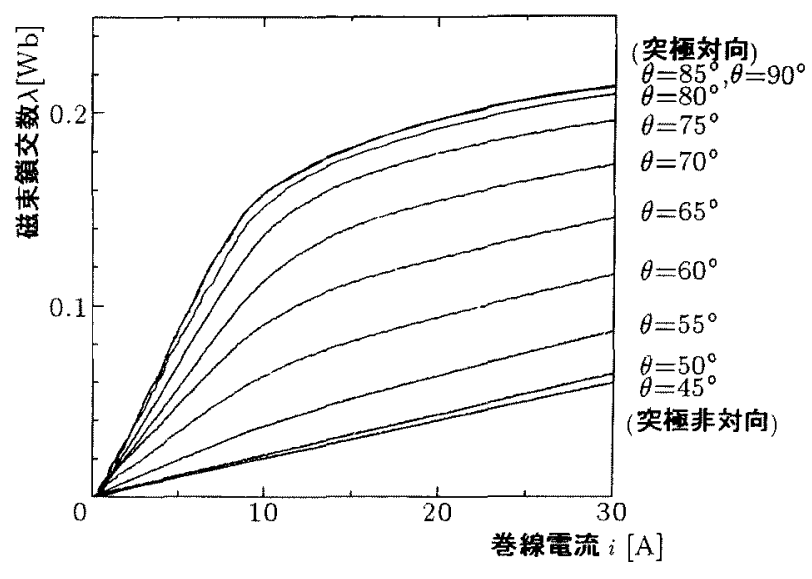

図 3 共試 SRM の磁化特性

Fig. 3. Magnetization characteristics of test motor.

\section{3. 磁化特性の簡易数式表現に基づく位置推定原理}

$\langle 3 \cdot 1\rangle$ 磁化特性の数式表現 磁化特性の数式モ学ル

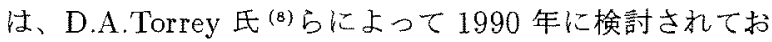
り、巻線電流 $i$ および回転子位置 $\theta$ の関数として磁束鎖交数 $\lambda$ を次式で定義している。

$$
\lambda(i, \theta)=a_{1}(\theta)\left(1-e^{a_{2}(\theta) i}\right)+a_{3}(\theta) i
$$

(2) 式中の $a_{1}(\theta) \sim a_{3}(\theta)$ は次式で与えられる。

$$
\begin{aligned}
a_{m}(\theta) & =\sum_{k=0}^{\infty} A_{m k} \cos (k \alpha \theta) \\
\text { ただし、} & \quad m=1,2,3
\end{aligned}
$$

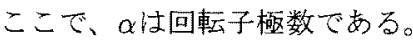

Torrey 氏らは (2) 式䒚 SRM の解析モデルとして提案し たが、本研究ではSRMの位置センサレス化を目的に、(2) 式を出発点とした回転子位置推定のための磁化特性の簡易 数式表現を提案するもので、以下、簡易数式化について説 明守劣。

\section{$\langle 3-2\rangle$ 磁化特性の簡易数式表現}

$\langle 3 \cdot 2 \cdot 1\rangle$ 簡易数式化手順 $e^{x}$ のテーラー展開は、

$$
e^{x}=1+x+\frac{x^{2}}{2}+\cdots+\frac{x^{n}}{n !}
$$

で与えられることから、(2) 式は次式に書き改められる。

$$
\lambda(i, \theta)=\sum_{n=1}^{n_{\text {max }}} L_{n}(\theta) i^{n}
$$

ここで、(5) 式中の位置の関数係数 $L_{n}(\theta)$ 㹥次式で記せる。

$$
L_{n}(\theta)=\sum_{k=0}^{\infty} L_{n k} \cos (k \alpha \theta)
$$


(5) 式の電流の最大次数 $n_{\max } 、(6)$ 式のフーリエ保数 $L_{n k}$ は、図 3の磁化特性の測定值を基に、最少二乗近似および DFT 解析により決定できる。

\section{（stage1） 電流展大次数 $n_{\max }$ の決定}

巻線電流值の増加に対して磁気飽和現象が最も顕著とな るの泣、回転子位置が完全対向時 $\left(\theta=90^{\circ}\right)$ で、この場合 に(5) 式の電流次数 $n$ により高次の成分が含まれる。し たがって、電流の最大次数 $n_{\max }$ を決定するためには、完 全対向時の磁化特性に対して (7) 式により最小二乗近似を 行えばよい。

$$
\left.\lambda(i)\right|_{\theta=90^{\circ}}=\sum_{n=1}^{\infty} L_{n} i^{n}
$$

得られた最小二乗近似結果では、電流の 7 次以上の係数 $L_{7} 、 L_{8} \cdots$ が 6 次までの係数 $L_{1} \sim L_{6}$ に比べて十分小さく 無視できる程度であったため、電流の最大次数の低次化を 目的に $n_{\max }=6$ とした。

\section{(stage2) フーリエ係数 $L_{n k}$ の決定}

他の回転子位置についても順次 (stage1) を行えば、回転 子位置に対する $L_{1} \sim L_{6}$ の值学得る。一例として、回転子 位置に対子る $L_{1}$ の空間分布学図 4 に示す。同図で回転子位 置 $0^{\circ} \sim 40^{\circ}$ のデー夕は、モー夕構造の対称性から $90^{\circ} \sim 50^{\circ}$ のデー夕を置き換えており、 $L_{1} \sim L_{6}$ の空間分布の DFT 解 析により各フーリエ係数 $L_{n k}$ を決定できる。

(stage1)、(stage2) で決定した、電流の最大次数 $n_{\max }$ お よび各フーリエ係数 $L_{n k}$ を(5) 式に代入して得た、完全対 向時の磁化特性を図 5に示寸。同図から、(5) 式で得られた 磁化特性は測定值に対し、10A 以上の飽和領域で大きな誤 差を持つことがわかる。この原因注、基淮とする磁化特性 の測定值の角度分割数が少なく、 $k=8$ 次以上の高次成分は DFT 解析で海得られないためで、測定角度の分割数の増加 によりこの誤差は低減できる。しかし、測定データ数の増加

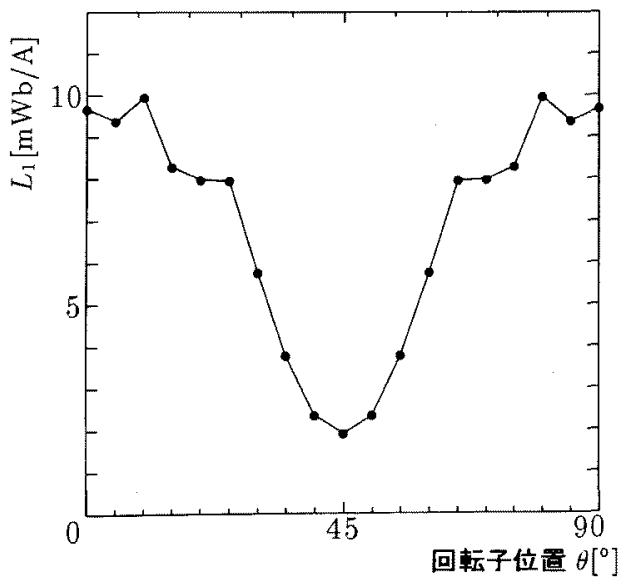

図 4 係数 $L_{1}$ の空間分布

Fig. 4. Space distribution of coeffcient $L_{\mathrm{I}}$.

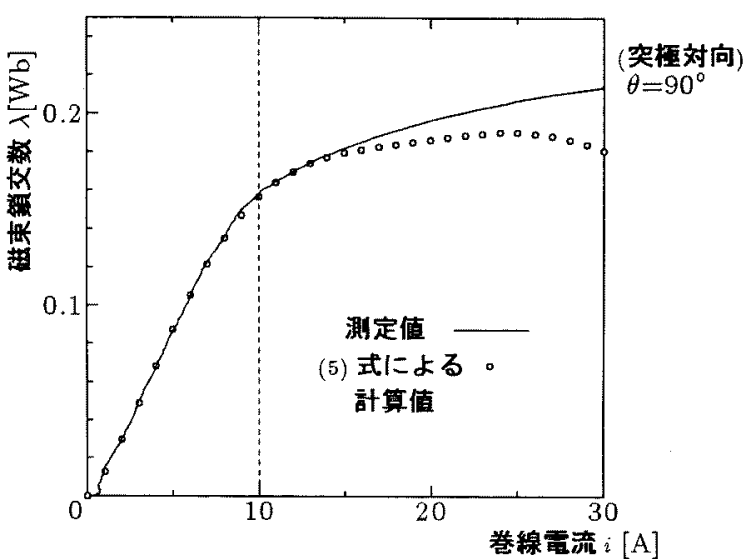

図 5 (5) 式で得られた完全対向時の磁化特性

Fig. 5. Magnetization characteristic at aligned position obtaind by expression (5).

は実用上の観点から望ましくなく、位置の関数係数 $L_{n}(\theta)$ の高次化は数式の簡素性を失わせるため、以下に磁化特性 の領域分割による簡易数式表現の精度改善策を述べる。

$\langle 3 \cdot 2 \cdot 2\rangle$ 非飽和・既和領域分割による簡易数式表現の 精度改善图5によれ佂、(5)式で得られた磁化特性は巻 線電流 $10 \mathrm{~A}$ までは十分な精度を持つ。そこで、境界值を

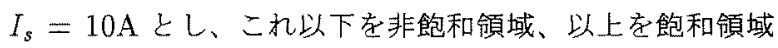
として簡易数式表現を再構成主る。この場合、(5) 式は次 式に畫改められる。

$$
\begin{gathered}
\lambda(i, \theta)=\sum_{n=1}^{n_{\text {max }}} L_{n}(\theta) i^{n}+\sum_{m=1}^{m_{\text {max }}} L_{s m}(\theta)\left(i-I_{s}\right)^{m} \\
\text { ただし、 } \quad i<I_{s} \text { のをき第 } 2 \text { 項 }\left(i-I_{s}\right)=0 \\
i \geq I_{s} \text { のをき第 } 1 \text { 項 } i=I_{s}
\end{gathered}
$$

ここで、(8) 式中の位置の関数係数 $L_{s m}(\theta)$ は次式で記せる。

$$
L_{s m}(\theta)=\sum_{k=0}^{\infty} L_{s m k} \cos (k \alpha \theta)
$$

(8) 式の $m_{\max } 、(9)$ 式の $L_{s m k}$ はそれぞれ飽和領域に おける電流の最大次数とフーリエ係数で、前述と同様に (stage1)、(stage2)により決定できる。決定した $m_{\max }=$ 3、 $L_{s m k}$ を(8) 式に代入して得られた磁化特性が図 6で、回 転子位置によらず測定值に対して最大誤差 $5 \%$ の範囲でー 致し、提案する簡易数式表現の妥当性が確認できる。

〈3-3）簡易数式表現 $1=$ 基亏く位置推定原理 （6)、(9) 式において 3 次以上 $(k \geq 3)$ のフーリエ係数が無視できる とし、2 次までが有効であることを前提とすれば、(8) 式は 次式に整理できる。

$$
A_{1} \cos (2 \alpha \theta)+B_{1} \cos (\alpha \theta)+C_{1}=0
$$

ここで、 $A_{1} 、 B_{1} 、 C_{1}$ はそれぞれ、 


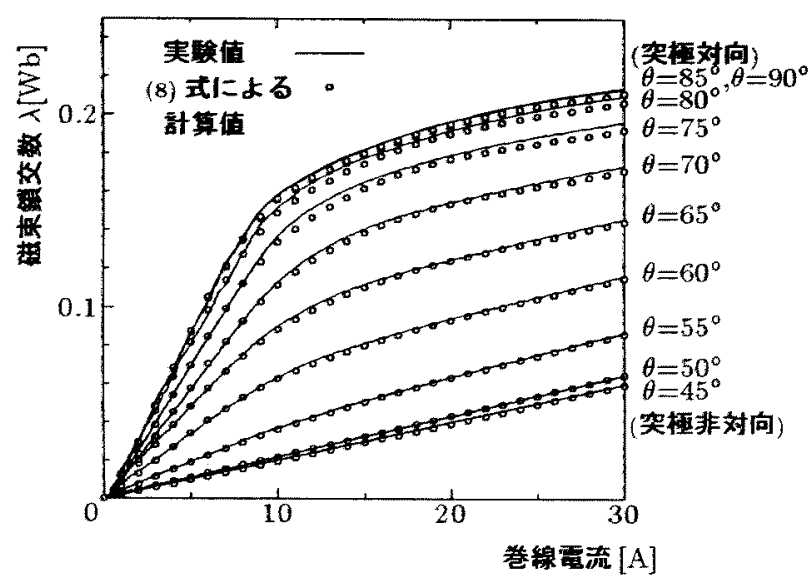

図 6 簡易数式表現 (8) 式で得られた磁化特性

Fig.6. Magnetization characteristics obtained by simple expression (8).

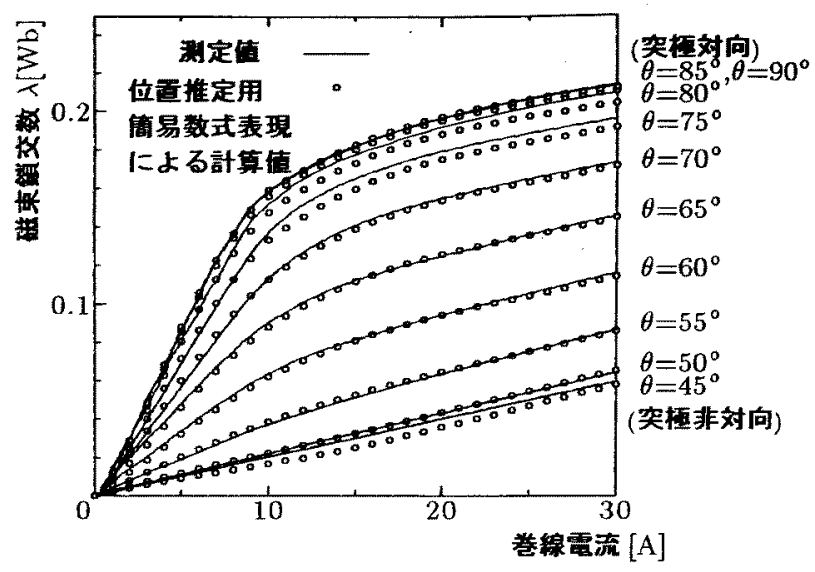

図 7 位置推定用の簡易数式表現による磁化特性

Fig. 7. Magnetization characteristics obtained by simple expression for position estimation.

三相各相で均等に位置推定を行うとすれば一相あたりの 推定期間は $30^{\circ}$ で、〈3・3〉で述べた点を考慮し、U相での推 定開始角を $47.5^{\circ}$ とすれ济、各相の推定期間はU 相 $47.5^{\circ} \sim$ $77.5^{\circ} 、 \mathrm{~V}$ 相 $17.5^{\circ} \sim 47.5^{\circ} \mathrm{W}$ 相 $77.5^{\circ} \sim 17.5^{\circ}$ となる。これ を基に推定部で最終的に得られた推定位置 $\theta_{e}$ を用いて、次 の制御周期に扔ける位置推定相を決定する。

\section{(step2) 磁束鎖交数の算出}

(step1) で選択した励磁相の磁束鎖交数入を変換器直流電 圧 $V_{d c} 、 \mathrm{PWM}$ バターンおよび巻線電流值 $i$ を用いて算出 する。ここで、演算精度向上のために $V_{d c}$ と PWM パター ンに対して、実測したスイッチング素子执よびダイオード の電圧降下抢よびスイッチング遅れを補正したものを巻線 印加電圧 $v_{p h}$ としている。

\section{(step3) 簡易数式表現に基うく位置推定}

巻線電流値 $i$ 己 (step2) で得られた磁束鎖交数 $\lambda$ を入力と

上述では、前提条件莸 2 次までのフーリエ係数が有効で あるとしたが、この条件が位置推定精度に及ぼす影響在考 察するため、(8) 式で 3 次以上のフーリエ係数を零とした 位置推定用の簡易数式表現で得られる磁化特性を图 7に示 す。図 6 との比較から、3次以上のフーリ工倸数を含む場合 に比心゙、回転子位置が非対向近傍 $\left(\theta<50^{\circ}\right)$ および対向近 傍 $\left(\theta>75^{\circ}\right)$ では測定值に対する誤差が大きくなっている

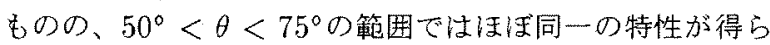
れていることがわかる。本来、非対向扔よび対向近傍では、 位置の変化に対する磁束鎖交数の变化が少なく、位置の推 定精度が低下することを考虑すれば、2 次までを有効しす る条件が位置推定精度に及代す影響は少ない。

\section{4. 簡易数式表現に基づく位置推定アルゴリズム}

$\langle 3 \cdot 3\rangle$ で述べた位置推定演算安中心と子る位置推定部の 構成文图8に示す。

(step1) 推定相の決定

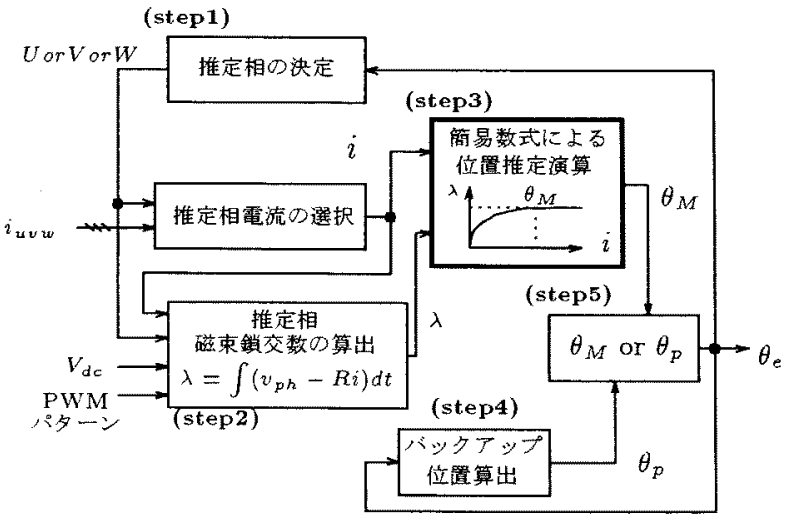

図 8 位置推定部の構成

Fig. 8. Position estimator configuration. 
ᄂ、回転子位置 $\theta_{M}$ を出力として得る。 (step4) バックアップ位置の算出

基本的には (step3) で得られる $\theta_{M}$ が回転子位置情報之な るが、諸種の原因により、これが必ずしも正確な値となら ない場合のバックアップデータとして、以下に説明する方 法で得られるバックアップ位置情報 $\theta_{p}$ 意用意する。

3 制御周期前の推定位置 $\theta_{\varepsilon}(n-3)$ と推定位置の差分に より算出した前回及び前々回の推定速度の平均 $\omega\left(n-\frac{3}{2}\right)$ を用いて、(13) 式により現在のバックアッブ位置情報 $\theta_{p}(n)$ を算出する。

$$
\theta_{p}(n)=\theta_{e}(n-3)+3 \omega\left(n-\frac{3}{2}\right) T_{s}
$$

ここで、 $T_{s}$ は制御周期である。

(step5) $\theta_{M}$ or $\theta_{p}$ の㟟択

図 9のフローチャートに従って、簡易数式表現より得ら れた推定位置 $\theta_{M}$ とパックアップ位置情報 $\theta_{p}$ の選抧を行う。 図中 (a) ( c) はノイズによる電流検出骙差や突極対向、非 対向近边での位置推定誤差に詨応させるために設けた条件 で、(a) は予測位置 $\theta_{p}$ の演算に用いる推定速度の信頼性を確 認、これをクリアした上で(b)では $\theta_{p}$ を基準にモデル推定 位置 $\theta_{M}$ の信頼性を確認、(c) 伤撛接する制御周期間で逆転 寸ることはないとする条件である。ここで、条件 (a)、(b) で用いた推定速度、位置の誥差許容値は実験的に決定した 値である。

\section{5. 実㖪システムと電流・速度制御系の構成}

〈5・1〉実駼システム構成 実駼に使用したシステム構 成在図 10に示す。コントローラに注固定小数点形 DSP(TI 社製 TMS320C50) を用い、ターンオン角 $\theta_{0}$ 、転流角 $\theta_{c}{ }^{(9)}$ 、 速度指命心 を入力として、位置推定演算在含を電流・速度 制御演算を制御周期 $127.2 \mu \mathrm{sec}$ で実行している。駆動変換

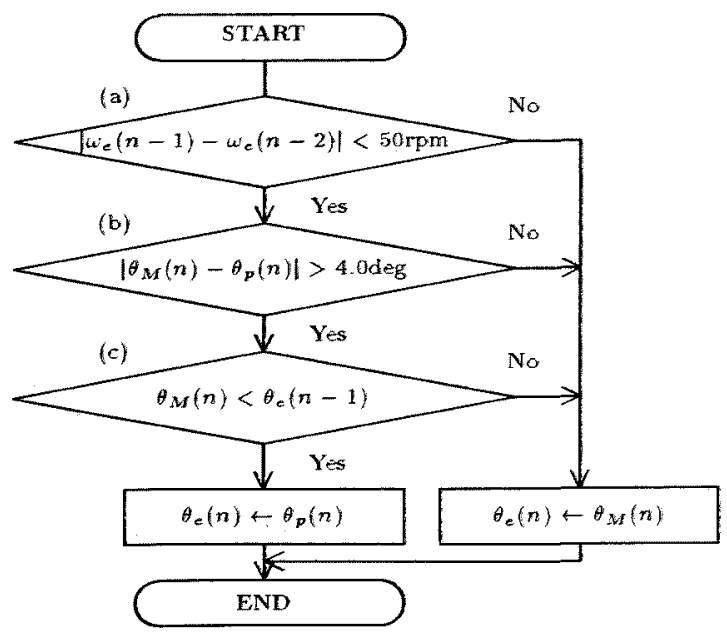

図 $9 \theta_{\boldsymbol{M}}$ と $\theta_{\epsilon}$ の選択

Fig. 9. Selection of $\theta_{M}$ and $\theta_{e}$.
器には 1 相あたりハーフプリッジ構成の)回路 (図 2(a) 参 照)を用い、各相電流はホール CT(LEM 社製 LA55-P 電 流出力形)、駆動回路直流電圧は絶縁形電圧七ンサ (アイ コーテンキ社製 DCPT-2510-1) を用いて検出している。 ロータリーエンコーダ (HEIDENHAIN 社彆 ROD426B) はモニタ用として設けており、実位置に対する推定位置の 評価に用いている。負荷に法定格出力 $1.54 \mathrm{~kW}$ 、定格速度 3000rpm の直流電動機 (安川電機社蹩 ミナーシャモータ UGMMEM-50AA1) 発電機上して用いている。

（5・2）位置センサレス雷流・速度制御系の满成 位置 センサレス駆動時の電流・速度制御系の構成文図 11に示す。 推定位置の差分により算出した值衣ローパスフィルタ(カッ トオフ周波数 $200 \mathrm{~Hz}$ ) で処理して得られる推定速度山。在 いて、速度 PI 制御老行っている。電流制御妨矩形波電流駆 動老前提に、速度 PI 演算で得られ充電流波高檤指合 $I_{\text {max }}^{*}$ 飞䖽出電流值 $i$ 比較し、印加電圧 $v$ を

$$
i \leq I_{\max }^{*} \text { の時 } v=V_{o n}, i>I_{\max }^{*} \text { の時 } v=0
$$

として、推定位置 $\theta_{e}$ に基づきPWM 制御を行っている。(14) 式の $V_{o n}$ 、図11中の $\theta_{0} 、 \theta_{c}$ などの制御パラメータは、運転 状態に応じて夷伢的に決定しえ值を用いている。

\section{6. 実験結果}

〈6-1〉位置センサレス制御時の出カトルクー速度特性

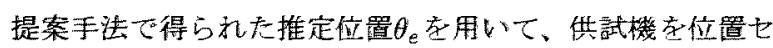
ンサレス制御した場合の出力トルクー速度特性を図 12 亿示

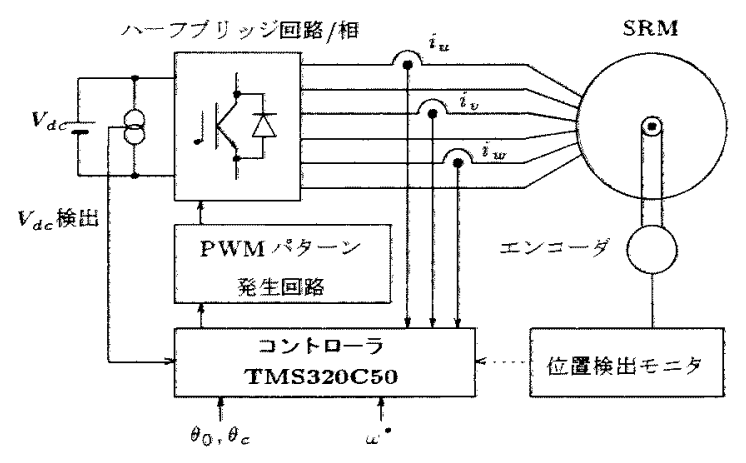

図 10 実験システム構成

Fig. 10. Experimental system configuration

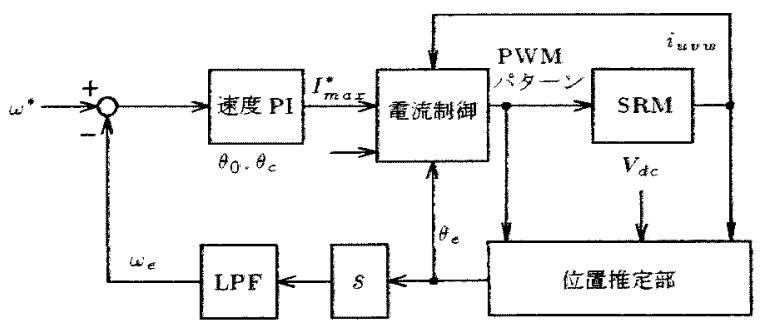

図 11 電流・速度制御采の構成

Fig. 11. Construction of current and speed regulators. 
す。負荷機の最大速度の制約から、4000 rpm(供試機の定格 速度の 74\%に相当) までの特性となっているが、0〜100\% の負荷トルク範囲において、最大速度比 1:20の良好な位置 センサレス速度制御特性が確認できる。

速度 4000 rpm/定格負荷トルク時の瞬時的な位置センサ レス制御特性を図 13 に示す。この場合の電流波高值は $16 \mathrm{~A}$ 程度と飽和領域での運転に相当する条件であり、実位置 $\theta_{r}$ と推定位置 $\theta_{e}$ との砖差 $\Delta \theta\left(=\theta_{r}-\theta_{e}\right)$ は平均的に零で、最 大でも機械角 $2^{\circ}$ と提案手法により良好な位置推定精度が確

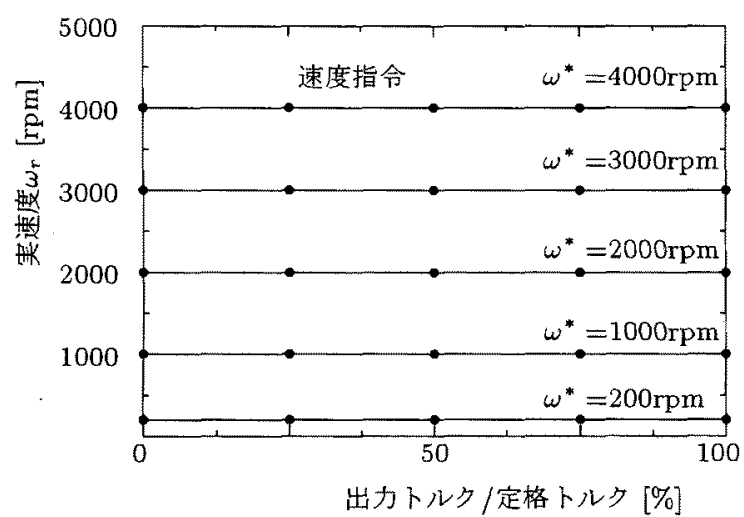

図 12 出力トルクー速度特性

Fig. 12. Output torque - speed characteristics.
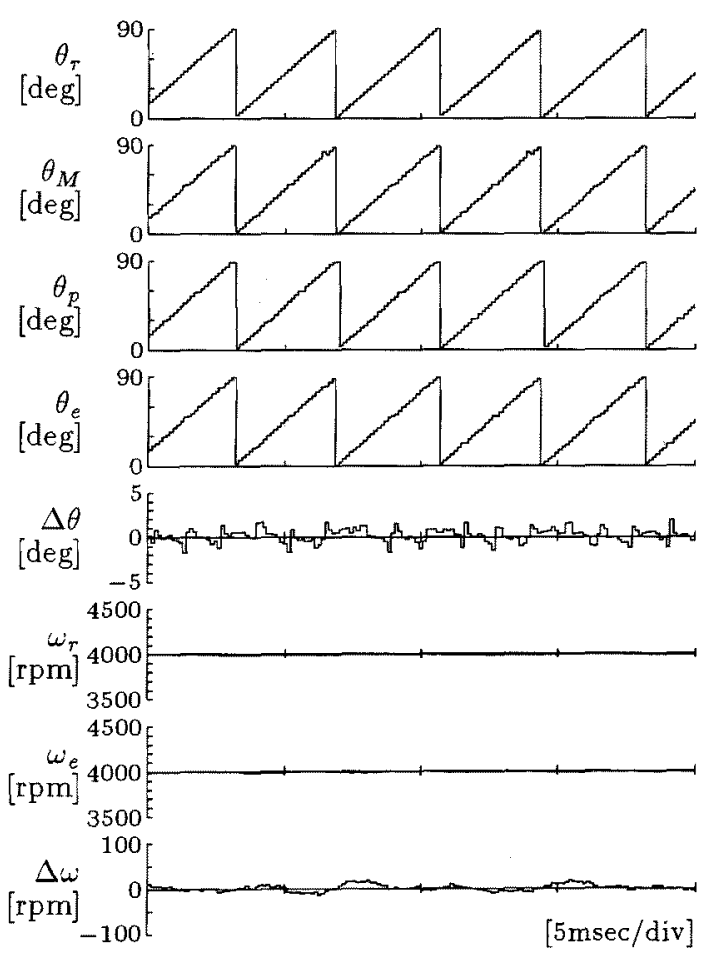

図 13 センサレス制御特性 (4000rpm, 定格負荷) Fig. 13. Position sensorless drive characteristics(4000rpm, rated load).
認できる。また、推定速度 $\omega_{e}$ 壮実速度 $\omega_{r}$ と一致し、速度指 令に対して精度の良い速度制御が実現されている。

図 14は速度 $200 \mathrm{rpm} /$ 無負荷時の特性で、この場合の電 流波高值は $3 \mathrm{~A}$ 程度で線形領域での運転に相当し、磁束鎖 交数に対する位置の推定感度が低下寸る領域である。同図 で位置誤差 $\Delta \theta$ がほぼ周期性を持って現れるのは、位置推定 感度の低下に伴い、磁束鎖交数算出時の補正演算における 微小な誤差の影響が大きくなったためであるが、位置誤差 は平均的に零で、最大でも機械角 50 程度と比較的良好な位 置推定精度が得られ、低速時でも指令速度に対して比較的 精度の良い速度制御が実現されている。

〈6-2〉加速時の位置センサレス制御特性可変速時の 提案手法の安定性在確認するため、200rpm から 4000rpm までのランプ速度指令山゙を与えた場合の位置センサレス制 御特性图 15 に示す。このとき、4000 rpm 時に定格負荷卜 ルクを生じるように直流発電機の負荷抵抗を与え、加速度

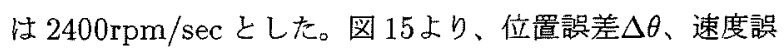
差 $\Delta \omega$ は、それぞれ最大で $4^{\circ} 、 70 \mathrm{rpm}$ と提案手法により可 変速時にも安定な位置センサレス制御特性が確認できる。

\section{7.あとがき}

本論文では、固定子/回転子が $6 / 4$ 、定格出力 $1.5 \mathrm{~kW}$ の 三相 SRM を対象に、磁化特性の簡易数式表現に基づく位

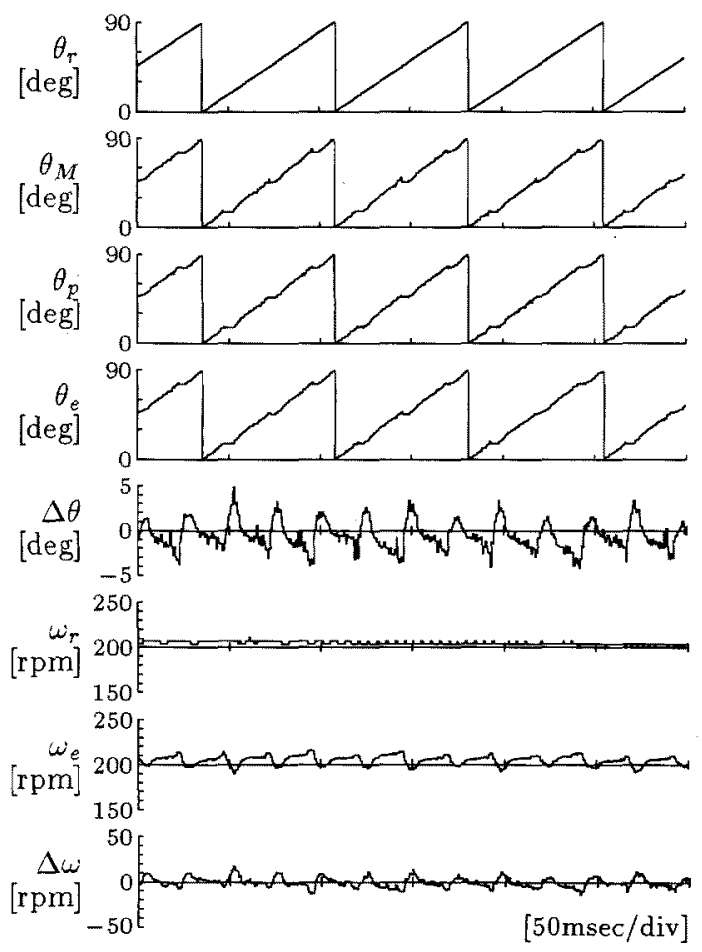

図 14 センサレス制御特性 (200rpm, 無負荷) Fig. 14. Position sensorless drive characteristics(200rpm, no load). 


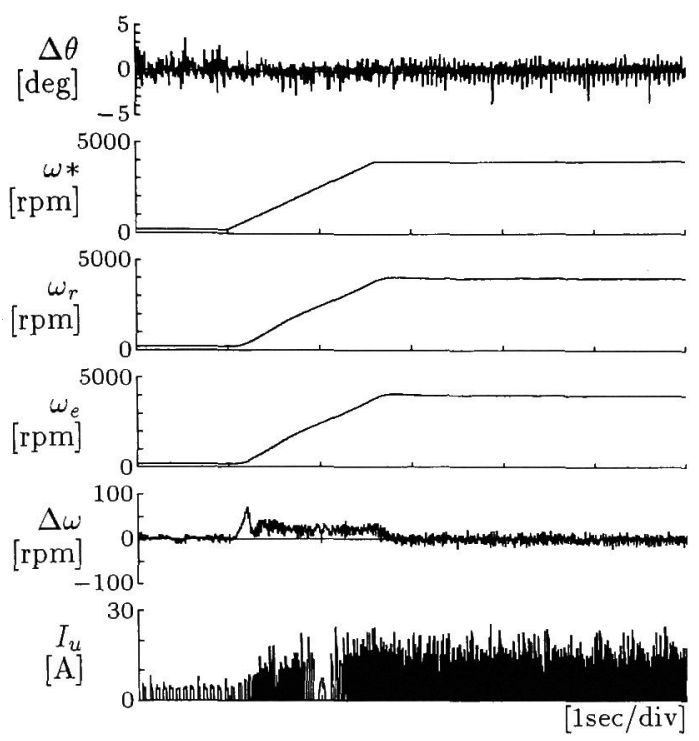

図 15 加速時のセンサレス制御特性

Fig. 15. Acceleration characteristics for the ramp speed command.

置推定アルゴリズムを提案した。安価な固定小数点形 DSP を用いた制御システムにより、実験的に提案手法の実用性 の評価を行った。提案手法により、負荷条件に関らず $1: 20$ の可変速範囲で安定な位圆センサレス駆動が実現できるこ とを確認した。得られた成果は、コンプレッサやファンな どの廉価な可変速システムに対して、十分実用性のあるも のと考えている。

(平成 11 年 06 月 07 日受付, 平成 12 年 02 月 02 日再受付)

\section{文献}

(1) T.J.E.Miller, et al ; "Switched Reluctance Drives", IEEE/IAS Ann. Meeting, Tutorial Course Text, 1990.

(2) B.C.Mecrow; "Fully Pitched-Winding Switched-Reluctance and Stepping-Motor Arrangements", IEE Proceedings-B, vol.140, No.1, pp.61-70, Jan., 1993.

(3) I. Husain and M.Ehsani; "Rotor Position Sensing in Switched Reluctance Motor Drives by Measuring Mutually Induced Voltages", IEEE Trans. on Industry Applications, Vol30, No.3, pp.665-672, 1994.

(4) T J E Miller et al ; "A New Sensorless Method for Switched Reluctance Motor Drives", Proc. of IEEE/IAS Ann. Meeting, pp.564-570, 1997.

(5) L.Xu and J.Bu ; "Position Transducerless Control of Switched Reluctance Motor using Minimum Magnetizing Input", Proc. of IEEE/IAS Ann. Meeting, pp.553-539, 1997.

(6) P. Vas et. al ; "Position Sensorless Control of SRM Drive using ANN-Techniques" Proc. of IEEE/IAS Ann. Meeting: pp. 709-714, 1998

(7) S.Saha, K.Ochiai, T.Kosaka, N.Matsui and Y.Takeda ; "A New Modelling Approach for Switched Reluctance Motors" 平 10 電学産業応用部門全国大会講演論文集. Vol.I, No.15, pp.4144. 1998 .

(8) D.A.Torrey and J.H.Lang: "Modelling a nonlinear variablereluctance motor drive", IEE proceedings., Vol.137, Pt. B,
No.5, pp.314-326, Sept., 1990.

(9) T.J.E.Miller, et al ; "Switched Reluctance Motor and their control", Magna Physics Publishing and Clarendon Press Oxford, 1993

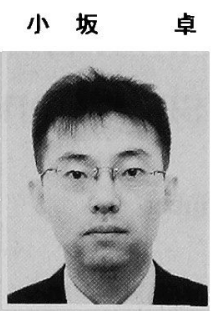

卓（正員） 1968 年 12 月 29 日生。1996 年 3 月名古 屋工業大学大学院博士前期課程電気情報工学専攻 修了。1999 年 3 月同大学院博士後期課程電気情 報工学専攻修了。1999 年 4 月同大学心゙ンチャー ビジネスラボラトリー非常勤講師、2000 年 4 月 同大学電気情報工学科助手、現在に至る。工学博 士。リラクタンス形モータの構造設計と制御に関 する研究に従事。

松井信行 (正員) 1943 年 5 月 7 日生。1968年 3 月名古屋

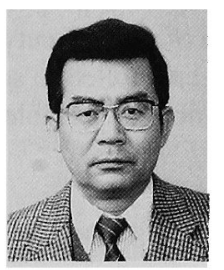
工業大学大学院修士課程修了。同年 4 月名古屋工 業大学助手、講師、助教授を経て、1985 年 4 月 同電気情報工学科教授、2000 年 4 月同大学副学 長、現在に至る。エ学博士。パワーエレクトロニ クスおよびモーションコントロールの研究と教育 に従事。計測自動制御学会、日本ロボット学会、 IEEE Senior 会員。

Subrata Saha （非会員） He was born in Calcutta, India in 1969.

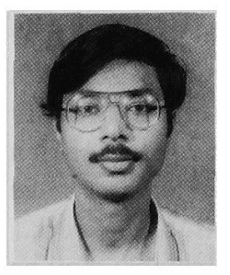
He received the M.Tech. and Ph.D degrees in Energy Systems engineering from Indian Institute of Technology, Bombay, India in 1993 and 1998, respectively. During Oct. 1997 to Mar. 1999, he has worked in Nagoya Institute of Technology as a researcher with the aid of Japanese Government Scholarship. From Apr. 1999, he has joined the Power Electronics Group of Matsushita Electric Industrial Co.Ltd.

武田洋次 (正員) 1943 年 11 月 10 日生。1968年 3 月大阪

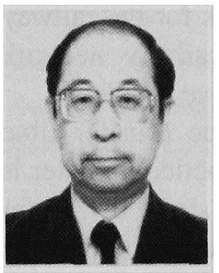
府立大学大学院修士課程修了。同年 4 月大阪拊立 大学助手、1993 年 4 月同教授、現在に至る。工学 博士。主として、モータの可変速制御システム、 リニアアクチュエータの研究に従事。IEEE、電 気情報通信学会、パワーエレクトロニクス研究会 会員。 